\title{
In vitro Dendrobium nobile plant growth and rooting in different sucrose concentrations
}

\author{
Ricardo T. de Faria; Fabiana N. Rodrigues; Luciana do V.R. Oliveira; Cláudio Müller \\ UEL, C. Postal 6001, 86051-990 Londrina-PR; E-mail: faria@uel.br
}

\begin{abstract}
Sucrose is a very important component in in vitro culture media, serving as a source of carbon and energy. In this paper, the rooting and in vitro growth of Dendrobium nobile Lindl (Orchidaceae) were studied using different sucrose concentrations $\left(0 \mathrm{~g} \mathrm{~L}^{-1} ; 5 \mathrm{~g} \mathrm{~L}^{-1} ; 10 \mathrm{~g}\right.$ $\mathrm{L}^{-1} ; 20 \mathrm{~g} \mathrm{~L}^{-1} ; 30 \mathrm{~g} \mathrm{~L}^{-1}$ and $60 \mathrm{~g} \mathrm{~L}^{-1}$ ), in a modified MS medium containing half the regular concentration of macronutrients at $\mathrm{pH}$ 5.8. Greater increases in plant height $(4.21 \pm 0.6 \mathrm{~cm})$ and high seedling multiplication (1:4) were observed in the $60 \mathrm{~g} \mathrm{~L}^{-1}$ sucrose treatment, even without the addition of plant hormones. Sucrose concentration in the culture medium did not influence in vitro plant rooting.
\end{abstract}

Keywords: Dendrobium nobile, Orchidaceae, carbohydrate, tissue culture.

\section{RESUMO}

Crescimento e enraizamento in vitro de plântulas de Dendrobium nobile sob diversas concentrações de sacarose

A sacarose é um componente muito importante no meio de cultura servindo como fonte de carbono e energia. Neste trabalho, avaliou-se o crescimento e enraizamento in vitro de plântulas de Dendrobium nobile Lindl. (Orchidaceae) cultivadas em diferentes concentrações de sacarose $\left(0 \mathrm{~g} \mathrm{~L}^{-1}, 5 \mathrm{~g} \mathrm{~L}^{-1} ; 10 \mathrm{~g} \mathrm{~L}^{-1} ; 20 \mathrm{~g} \mathrm{~L}^{-1} ; 30 \mathrm{~g} \mathrm{~L}^{-1}\right.$ e $60 \mathrm{~g} \mathrm{~L}^{-1}$ ), utilizando como base o meio MS com metade da concentração de macronutrientes e pH 5,8. No tratamento com $60 \mathrm{~g} \mathrm{~L}^{-1} \mathrm{de}$ sacarose observou-se maior crescimento em altura $(4,21 \pm 0,9 \mathrm{~cm})$ assim como uma alta taxa de multiplicação de mudas (1:4) mesmo sem adição de fitorreguladores. $\mathrm{O}$ acréscimo de sacarose no meio de cultura não influenciou o enraizamento in vitro das plantas.

Palavras-chave: Dendrobium nobile, orchidaceae, carboidrato, cultura de tecidos.

(Recebido para publicação em 25 de setembro de 2003 e aceito em 2 de julho de 2004)

$\mathrm{T}$ he high heterozygosity of Dendrobium nobile hybrids has attracted the attention of biotechnology companies for large scale clonal propagation of elite genotypes belonging to this genus (Faria \& Illg, 1995). The orchid species used in this experiment, Dendrobium nobile, is an epiphyte of Asian origin, found throughout tropical and subtropical Asia, as far east as the Fiji Islands and Southern Australia (Huber, 1994).

The source of carbon (sucrose, glucose or fructose) is a very important component in in vitro culture media. Carbon sources are added to the culture medium because of the light energy deficiency and low $\mathrm{CO}_{2}$ concentration present in in vitro conditions (Tombolato $\&$ Costa, 1998). Sucrose concentrations of 20 and $30 \mathrm{~g} \mathrm{~L}^{-1}$ are the most commonly used in orchid tissue culture studies (Arditti, 1974). Reports from several laboratories emphasize the importance of the source and concentration of sugars used to promote in vitro orchid seed germination, as well as plant growth (Arditti, 1967; Ernest, 1967).
Plants cultured in vitro often show a low photosynthesis rate and incomplete autotrophy (mixotrophic or heterotrophic plants). This accounts for the low survival rates of plants during the acclimation stage (Grout \& Price, 1987; Kozai,1988). The most common procedure is micropropagation of sprouts and plants in culture media that mimic greenhouse conditions, aiming to achieve a shorter adaptation period (Debergh, 1991).

According to Debergh (1991), the absence of sugar reduces contamination problems in the culture medium and allows plants to grow autotrophically in vitro, when sufficient $\mathrm{CO}_{2}$ is supplied and light intensity is increased. However, the presence of sugar in the culture medium is one of the factors that contribute to a significant increase in the production cost of micropropagated plantlets (Kozai, 1991).

Some researchers have been trying to solve the problem of in vitro autotrophic plant production adaptation. To achieve these objectives, the amount of sugar is reduced or omitted (Grout \& Price, 1987; Kozai, 1988) and light intensity and $\mathrm{CO}_{2}$ concentration are increased (Desjardins \& Laforge, 1988; Kozai et al., 1988).

Micropropagation requires, in many cases, the cultivation of explants under heterotrophic conditions, mainly in the sprout induction stage. At this stages, the explant generally consists of an agglomeration of sprouts, whose photosynthesis system is not able to supply energy for tissue growth and development (Kozai, 1992). Bearing in mind that each species has a different behavior, careful testing of partial decreases in sugar is recommended in the subsequent stages of the process, through assessment of the multiplication rate, growth, and quality of plants produced (Kozai, 1991).

Working with strawberry (cv. Campinas), Calvete et al. (2002) observed that the concentration of sucrose $\left(45 \mathrm{~g} \mathrm{~L}^{-1}\right)$ is ideal for the formation of roots; however, in the absence of this sugar, roots are not formed under in vitro cultivation.

This study was carried out to assess in vitro plant growth and rooting of Dendrobium nobile seedlings in culture media containing different sucrose concentrations. 


\section{MATERIAL AND METHODS}

Dendrobium nobile plantlets derived from seeds germinated in vitro were used with a mean initial height of 1.92 $\pm 0.5 \mathrm{~cm}$ and a mean fresh weight of $0.07 \pm 0.02 \mathrm{mg}$.

The MS medium (Murashige and Skoog, 1962), containing half its regular concentration of macronutrients and at pH 5.8 was used to assess plantlet growth and rooting. The sucrose concentrations added to the MS medium were: $\left(0 \mathrm{~g} \mathrm{~L}^{-1}\right) \mathrm{T}_{1} ;\left(5 \mathrm{~g} \mathrm{~L}^{-1}\right) \mathrm{T}_{2} ;\left(10 \mathrm{~g} \mathrm{~L}^{-1}\right)$ $\mathrm{T}_{3} ;\left(20 \mathrm{~g} \mathrm{~L}^{-1}\right) \mathrm{T}_{4} ;\left(30 \mathrm{~g} \mathrm{~L}^{-1}\right) \mathrm{T}_{5}$, and $\left(60 \mathrm{~g}^{-1}\right.$ $\left.\mathrm{L}^{-1}\right) \mathrm{T}_{6}$.

Flasks ( $250 \mathrm{ml}$ capacity) were used, containing $50 \mathrm{ml}$ of autoclaved culture medium each. Five plants were inoculated in each flask, closed and sealed with PVC film, and kept in a culture chamber adjusted to a 16-hour photoperiod (fluorescent bulbs); temperature was set around $25^{\circ} \mathrm{C}$. The study was carried out in a completely randomized design with ten replicates per treatment. Plantlet growth in height was assessed monthly for a period of four months. After that period, fresh weight, root length, and number of shoots were also assessed. The plantlets were transplanted to ceramic pots containing xaxim coir and transferred to a greenhouse with $50 \%$ of shading provided by a black polypropylene screen, $60 \%$ relative humidity, and temperature ranging from 25 to $28^{\circ} \mathrm{C}$. The data obtained were submitted to analysis of variance, Tukey test, and regression analysis.

\section{RESULTS AND DISCUSSION}

There were no significant differences regarding the plant height variable among the six different treatments in the period from 30 to 60 days (Table 1).

The treatments containing different sucrose concentrations presented significant mean plant height differences after ninety days from the beginning of the experiment. In $\mathrm{T} 6\left(60 \mathrm{~g} \mathrm{~L}^{-1}\right.$ of sucrose), plantlets showed greater growth in height when compared to the other treatments. After 120 days of

Table 1. Mean values for plant height (PH), assessed at different periods (30, 60, 90 and 120 days of culture), fresh weight (FW), root length (RL) and number of shoots (NS), in the different sucrose concentrations after 120 cultivation. Londrina, UEL, 2003.

\begin{tabular}{|c|c|c|c|c|c|c|c|}
\hline \multirow{3}{*}{$\begin{array}{l}\text { Treatments } \\
\mathrm{T} 1\left(0 \mathrm{~g} \mathrm{~L}^{-1}\right)\end{array}$} & \multicolumn{7}{|c|}{ Means } \\
\hline & \multirow{2}{*}{$\begin{array}{c}\mathrm{PH}(\mathrm{cm}) \\
30 \text { days } \\
2.04 \mathrm{a}^{2}\end{array}$} & \multirow{2}{*}{$\begin{array}{c}\mathrm{FW}(\mathrm{cm}) \\
60 \text { days } \\
2.15 \mathrm{a}\end{array}$} & $\begin{array}{l}\mathrm{PH}(\mathrm{cm}) \\
90 \text { days }\end{array}$ & $\begin{array}{l}\mathrm{PH}(\mathrm{cm}) \\
120 \text { days }\end{array}$ & $\begin{array}{l}\mathrm{FW}(\mathrm{mg}) \\
120 \text { days }\end{array}$ & $\begin{array}{l}R L(\mathrm{~cm}) \\
120 \text { days }\end{array}$ & $\begin{array}{l}\text { NS } 120 \\
\text { days }{ }^{1}\end{array}$ \\
\hline & & & 2.29 & 2.75 & $85.50 \mathrm{bc}$ & $1.94 \quad b$ & $2.0 \mathrm{~b}$ \\
\hline T2 $\left(5 \mathrm{~g} \mathrm{~L}^{-1}\right)$ & $1.98 \mathrm{a}$ & $2.11 \mathrm{a}$ & 2.32 & 2.89 & 75.80 bc & $2.96 a b$ & $3.4 a b$ \\
\hline T3 $\left(10 \mathrm{~g} \mathrm{~L}^{-1}\right)$ & $2.12 \mathrm{a}$ & $2.34 \mathrm{a}$ & $2.58 \mathrm{bc}$ & 3.09 & $70.90 \quad c$ & $4.00 \mathrm{ab}$ & $4.0 \mathrm{ab}$ \\
\hline $\mathrm{T} 4\left(20 \mathrm{~g} \mathrm{~L}^{-1}\right)$ & $2.05 \mathrm{a}$ & $2.24 \mathrm{a}$ & $2.64 \mathrm{bc}$ & 3.32 bc & $93.50 \mathrm{bc}$ & $3.34 \mathrm{ab}$ & $3.6 \mathrm{ab}$ \\
\hline T5 $\left(30 \mathrm{~g} \mathrm{~L}^{-1}\right)$ & $2.10 \mathrm{a}$ & $2.27 \mathrm{a}$ & $2.95 \mathrm{~b}$ & $3.56 \mathrm{~b}$ & $122.40 \mathrm{~b}$ & $4.79 \mathrm{a}$ & $3.2 a b$ \\
\hline T6 $\left(60 \mathrm{~g} \mathrm{~L}^{-1}\right)$ & $1.95 \mathrm{a}$ & $2.09 \mathrm{a}$ & $3.54 \mathrm{a}$ & $4.21 \mathrm{a}$ & $171.70 \mathrm{a}$ & $4.75 \mathrm{a}$ & $4.4 \mathrm{a}$ \\
\hline C.V.\% & 11.32 & 16.06 & 16.29 & 10.18 & 15.63 & 25.41 & 14.79 \\
\hline DMS & 0.62 & 0.45 & 0.42 & 0.56 & 30.0 & 1.62 & 1.04 \\
\hline
\end{tabular}

${ }^{2}$ Means followed by the same letter in the column do not differ according to the Tukey test at $5 \%$ probability.

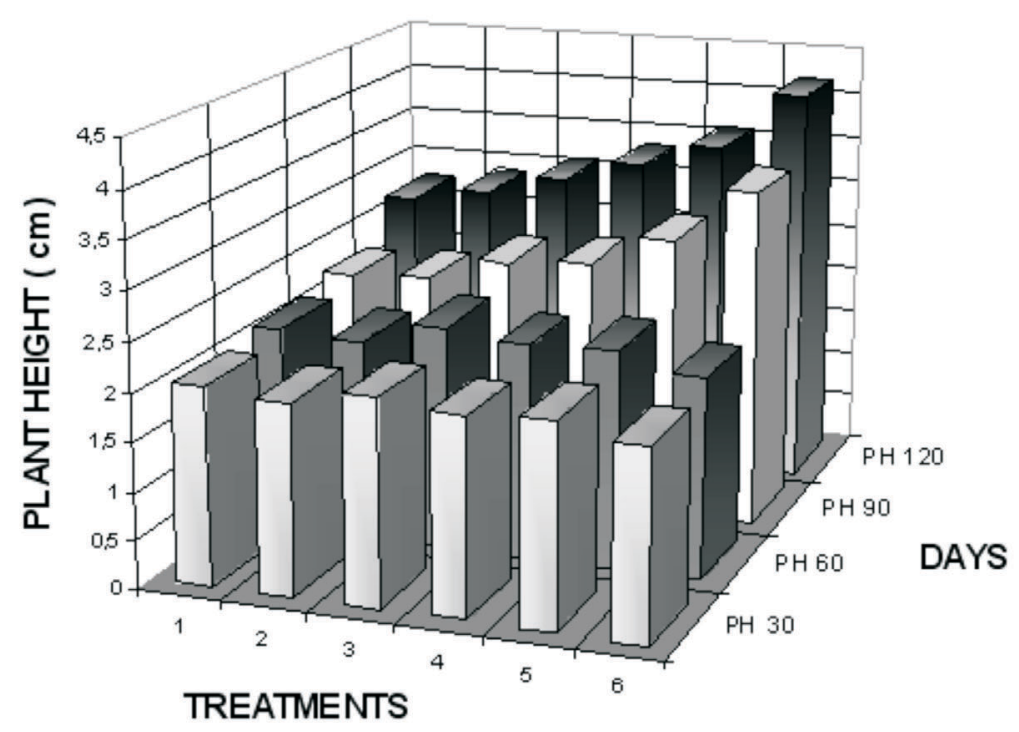

Figure 1. Plant height mean values $(\mathrm{PH})$, according to sucrose concentration in the culture medium and the time in culture (30, 60, 90 e 120 days). Treatments:T1 $\left(0 \mathrm{~g} \mathrm{~L}^{-1}\right)$; T2 $\left(5 \mathrm{~g} \mathrm{~L}^{-1}\right)$; T3 (10 $\left.\mathrm{g} \mathrm{L}^{-1}\right)$; T4 (20 $\left.\mathrm{g} \mathrm{L}^{-1}\right)$; T5 (30 $\left.\mathrm{g} \mathrm{L}^{-1}\right)$ e T6 $\left(60 \mathrm{~g} \mathrm{~L}^{-1}\right)$. Londrina, UEL, 2003.

culturing, the superiority of use of a higher sucrose concentration $\left(60 \mathrm{~g} \mathrm{~L}^{-1}\right)$ became evident based on explant growth in height. Similar results were observed considering plant fresh weight (FW) (Table 1).

Plantlets grown in the six different treatments began to sprout after the second month, even in the absence of plant hormones.

The assessment of mean root length (RL) values and number of shoots (NS) in plantlets from each treatment indicated that there were no significant differences between treatments, except when sucrose was not added to the culture medium, in which case root growth and shoot production were inhibited (Table 1). According to Mc Cown (1998), in vitro root formation does not occur when photosynthesis products are supplied in insufficient quantities.

In Figure 1 we can observe that in vitro growth of Dendrobium nobile plantlets was directly proportional to the sucrose concentration in the culture medium, after culturing for 120 days. The highest sucrose concentration in the culture medium $\left(60 \mathrm{~g} \mathrm{~L}^{-1}\right)$ presented the best result, with the greatest mean plant height value $(4.21 \pm 0.9 \mathrm{~cm})$. 


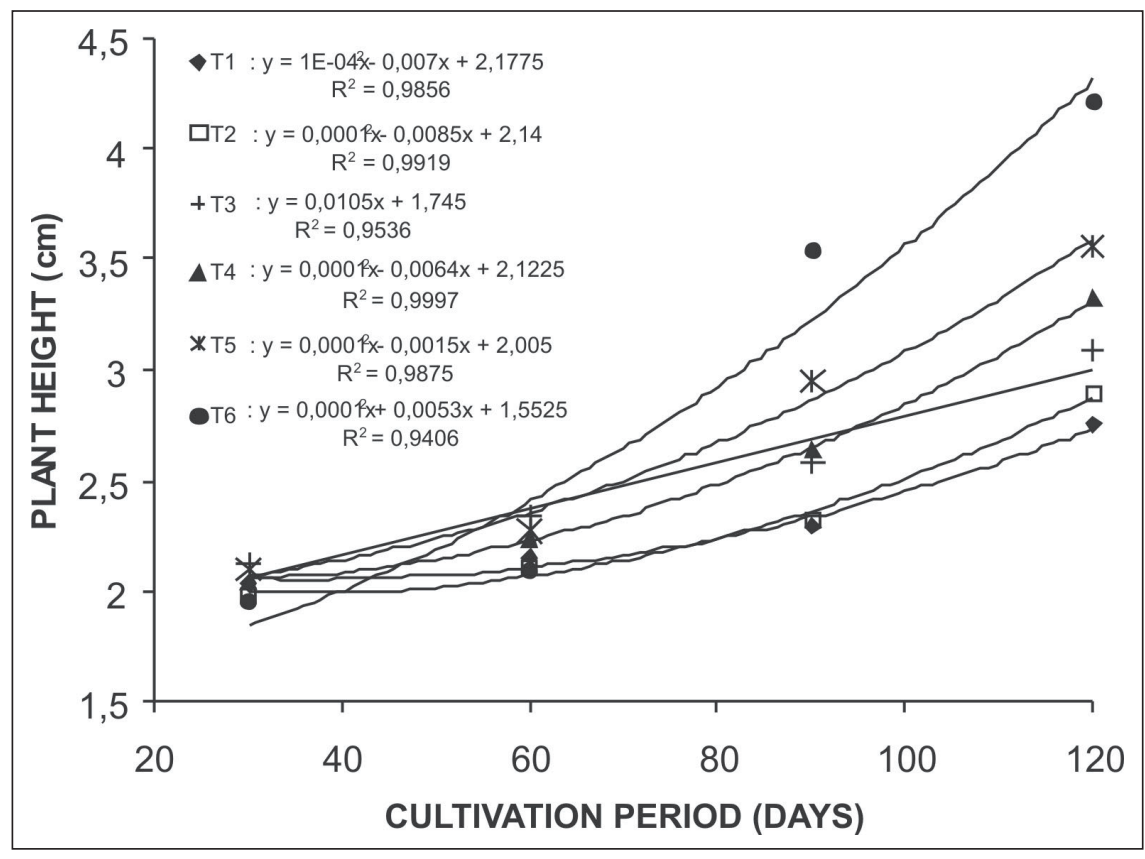

Figure 2. Curves of growth in vitro of Dendrobium nobile in agreement with the different sucrose dose: T1 $\left(0 \mathrm{~g} \mathrm{~L}^{-1}\right)$; T2 $\left(5 \mathrm{~g} \mathrm{~L}^{-1}\right)$; T3 $\left(10 \mathrm{~g} \mathrm{~L}^{-1}\right)$; T4 $\left(20 \mathrm{~g} \mathrm{~L}^{-1}\right)$; T5 $\left(30 \mathrm{~g} \mathrm{~L}^{-1}\right)$ e T6 $\left(60 \mathrm{~g}^{-1}\right.$ $\left.\mathrm{L}^{-1}\right)$ assessed in different periods. Londrina, UEL, 2003.

Collins \& Dixon (1992) studied different sucrose concentrations in in vitro culturing and observed that for the Australian terrestrial orchid Diuris longifolia, $20 \mathrm{~g} \mathrm{~L}^{-1}$ sucrose plus charcoal had a similar rooting effect as $40 \mathrm{~g} \mathrm{~L}^{-1}$ sucrose without charcoal. According to Kerbauy (1993), high agar levels, together with sucrose, promote great longitudinal root growth and lateral aerial growth, while low levels of these components favor the formation of protocorms in in vitro culture of Oncidium varicosum (Orchidaceae). Ishii et al. (1998) observed that in Phalaenopsis the presence of sucrose in the culture medium caused protocorm formation and its absence caused callus proliferation.

The mean root length (RL) values and mean number of shoots (NS) were not influenced by the increase in sucrose concentration in the culture medium, as $5 \mathrm{~g} \mathrm{~L}^{-1}$ would be sufficient. Without sucrose, smaller plant height increase, shorter root length, and a lower rate of shoot multiplication were observed.

Studies on micropropagation show that the presence of sugar in the culture medium is important for root development and shoot multiplication, as well as for plant height increase
(Kozai, 1991). Song et al. (1999) reported that a culture medium containing $3 \mathrm{~g} \mathrm{~L}^{-1}$ of Peters 10-30-20 commercial rate, sucrose $\left(20 \mathrm{~g} \mathrm{~L}^{-1}\right)$, banana pulp (60 $\left.\mathrm{g} \mathrm{L}^{-1}\right)$, and agar $\left(4 \mathrm{~g} \mathrm{~L}^{-}\right.$ $\left.{ }^{1}\right)$ was efficient to promote the vertical growth and rooting of Dendrobium nobile plants derived from in vitrogerminated seeds. Mitra et al. (1998) observed that Dendrobium Sw. roots in culture medium without sucrose did not develop, even when cultured within an atmosphere enriched with $\mathrm{CO}_{2}$. The best culture medium combination for the micropropagation of Dendrobium joannie Ostenhault was 3\% sucrose supplemented with 1 ppm of IAA, IBA, or NAA (Madhuri et al., 1990).

It is important to verify whether plants cultured in no sucrose medium (0 $\left.\mathrm{g} \mathrm{L}^{-1}\right)$ would be more successful during the acclimation stage, as they were submitted to conditions that were quite similar to normal greenhouse conditions. These effects are still under observation. According to Vij et al. (1996) Vanda cristata Lindl. plantlets obtained from protocorms cultivated in culture medium with a reduced sucrose concentration (from 0.5 to $2 \mathrm{~g} \mathrm{~L}^{-1}$ ) showed a success rate of $80 \%$ when transferred to greenhouse conditions.
Finally, a positive relationship between increase in sucrose concentration and increase in plant height was verified, as both treatments showed an increase in plant height as sucrose concentration increased. Treatment T6 presented a higher curve in relation to the treatment period, with an $R_{2}$ of 0.9406 , while treatment $\mathrm{T} 1$ presented a lower curve in relation to the treatment period, with an $\mathrm{R}_{2}$ of 0.9856 (Figure 2).

This increase in the amount of sucrose in the culture should be taken with caution and should not be progressive, because, according to Cappellades et al. (1991) and Hdider \& Desjardins (1994), high sucrose concentrations in in vitro cultures favor carbohydrate accumulation and hinder photosynthesis.

Sucrose concentration influenced growth and accumulation of biomass (fresh weight) of Dendrobium plantlets propagated in vitro. The presence of 60 $\mathrm{g} \mathrm{L}^{-1}$ sucrose in the culture medium was the most efficient treatment for increasing height and fresh weight of plants cultured in vitro.

\section{ACKNOWLEDGEMENT}

We are grateful to $\mathrm{CNPq}$ for financial support.

\section{CITED LITERATURE}

ARDITTI, J. Factors affecting the germination of orchid seeds. The Botanical Review, v.33, p.1-97, 1967.

ARDITTI, J. Orchid Biology. Reviews and perspectives I. Ed. Joseph Arditti. 1974. 293 p. CALVETE, E.O.; KAMPF, A.N.; SUZIN, M. Concentração de sacarose no enraizamento in vitro de morangueiro. Horticultura Brasileira. Brasília, v.20, n.2, p.186-191, 2002.

CAPPELLADES, M.; LEMEUR, R.; DEBERGH, P. Effects of sucrose on starch accumulation and rate of photosynthesis in Rosa cultured in vitro. Plant Cell, Tissue and Organ Culture, v.25, n.1, p.21-26, 1991.

COLlins, M.T.; DIXON, K.W. Micropropagation of an Australian terrestrial orchid Diuris longifolia R Br. Australian Journal of Experimental Agriculture, v.32, p.131-135, 1992.

DEBERG, P.C. Control of in vitro plant propagation. In: CROCOMO, O.J.; SHARP, W.R.; MELO, M. (Ed.) Biotecnologia para produção vegetal. Piracicaba: CEBTEC, FEALQ, 1991. p.3-8. 
DESJARDINS, Y.; LAFORGE, F. Effect of $\mathrm{CO}_{2}$ enrichment and hight light intensity on the development of autotrophy and growth of tissue cultured strawberry and Asparagus plants in vitro. In: Book of Abstracts. Int. Symp. Hight technologyc in protected cultivation, Hamamatsu, Japan, 1988, p.12-15.

ERNEST, R. Effects of carbohydrate selection on the growth rate of freshly- germinated Phalaenopsis and Dendrobium seed. American Orchid Society Bulletin, v.36, p.1068-1073, 1967. FARIA, R.T., ILLG, R.D. Propagação clonal de híbridos de Dendrobium nobile Lindl In: CONGRESSO BRASILEIRO DE FLORICULTURA E PLANTAS ORNAMENTAIS, 10., 1995, Campinas. Anais. Campinas: ED. SBF, 1995. p.40 - 41.

GROUT, W.W.; PRICE, F. The establishment of photosynthetic independence in strawberry cultures prior to transplanting. In: DUCATÉ, G.; JACOB, M.; SIMEON, A. (Ed.) Plant micropropagation in horticultural industries. Symposium. Florizel Arlon: Belgium, 1987. p.55-60.

HDIDER, C.; DESJARDINS, Y. Effects of sucrose on photosynthesis and phosphoenolpyruvate carboxylase activity of in vitro cultured strawberry plantlets. Plant Cell, Tissue and Organ Culture, v.1, n.36, p.27-33, 1994.
HUBER, G. Onde se desenvolvem as orquídeas. In: Orquídeas. Ed. Expressão e Cultura. 5ed. Rio de Janeiro, 1994. p.14-16.

ISHII, Y.; TAKAMURA, T.; GOI, M.; TANAKA, M. Callus induction and somatic embriogenesis of Phalaenopsis. Plant Cell Reports, v.17, p.446450, 1998.

KERBAUY, G.B. The effects of sucrose and agar on the formation of protocorm-like bodies in recalcitrant root tip meristems of Oncidium varicosum (Orchidaceae). Lindleyana, v.8, p.149154, 1993.

KOZAI, T. High technology in protected cultivation - from environment control engineering point of view. In: SPECIAL LECTURES HORTICULTURE IN HIGH TECHNOLOGY ERA. Symposium on High Technology Protected Cultivation. Tokyo, Japan,10-11, 1988. p.3-43.

KOZAI, T. Photoautotrophic micropropagation. In Vitro, v.27, p.47-51, 1991.

KOZAI, T. A new cost effective micropropagation of the orchid. In vitro, v.27, p.47, 1992.

KOZAI, T.;KOYAMA, Y.; WATANABE, I

Multiplication of potato plantlets in vitro with sugar-free medium under high photosynthetic photon flux. Acta Horticulture, v.230, p.121-127, 1988

MADHURI, S.; VASUNDHARA, G.; SHARON M. Micropropagation of Dendrobium joannie Ostenhault. Journal of the Orchid Society of India. v.4, n.145-148, 1990 .
MC COWN, B.H. Adventitious rooting of tissue cultured plants. In: DAVIS, T.; HAISSIG, B.E.; SANKLA, N. (Ed.) Adventitious root formation in cuttings. Portland-Oregon: Discorides, 1988. v.2, p.289-299.

MITRA, A; DEY, S.; SAWARKAR, S.K. Photoautotrophic in vitro multiplication of the orchid Dendrobium under $\mathrm{CO}_{2}$ enrichment. Biologia Plantarum, v.41, p.145-148, 1998.

MURASHIGE, T.; SKOOG, F. A revised medium of rapid growth and biossays with tissue cultures. Physiologia Plantarum, v.15, p.473-497, 1962.

SONG, M.K.R.; SILVA, G.L.; FARIA, R.T; TAKAHASHI, L.S.A. Análise do crescimento e enraizamento in vitro de híbridos de Dendrobium nobile Lindl. (Orchidaceae) semeados em diferentes meios de cultura. In: CONGRESSO BRASILEIRO DE FLORICULTURA E PLANTAS ORNAMENTAIS, 12., 1999, Jaboticabal, Anais. SP., Brasil. 1999, p.110.

TOMBOLATO, A.F.C.; COSTA, A.M.M. Micropropagação de plantas ornamentais (Boletim Técnico, $\mathrm{n}^{\circ}$ 174), Campinas: Instituto Agronômico. 1998, 72 p.

VIJ, S.P.; VISHAL, S; SHARMA, V. Regenerative competence of Vanda cristata perianth segments: a study in vitro. Journal of the Orchid Society of India, v.10, p.25-29, 1996. 